\title{
Destination Choice of Higher Education among the Local Secondary School Students in Sarawak
}

\author{
Winnie Wong Poh Ming \\ University College of Technology Sarawak. \\ winniewong@ucts.edu.my
}

\begin{abstract}
Destination choice of higher education has long been a subject of international research. The higher education sector in Malaysia is currently experiencing intense competition as many higher education institutions are mushrooming in the market. As a result of this, students now face more complexities when choosing a suitable higher learning institution for their studies. Hence, the primary objective of this study is to propose a valid framework that determines the most significant determinants of students' decisions on choosing higher education institutions among local students in Sarawak. Specifically, the purpose of this study is to investigate the relationship strengths between job perspectives, reputation of institution, location, cost, parental advice, peer influence, and student's choice intention. This study takes on the primary data collection approach. Data was collected through a complete set of questionnaire in a survey. Non-probability sampling method (purposive sampling) was used in the process of data collection. A total sample of 324 secondary school students participated in this study. The SmartPLS (version 3.2.6) was utilised to perform the Partial Least Square-Structural Equation Modeling (PLS-SEM) estimation procedure to examine the proposed direct and indirect relationship. Interestingly, the results indicated that reputation of university and parents' advice contributed the most to students' decisions regarding their higher education choice. Current findings of the study may be informative and can play a role as a basic guideline for future scholars. The findings may also assist marketers of higher education institutions to understand the concept of "business-to-students" before promoting and convincing more potential students. Several research limitations, implications, and recommendations for future research have also been highlighted in the study.
\end{abstract}

Keywords: Job prospective, Reputation of Institution, location, cost, parents' advice, student intention

\section{Introduction}

Vast demographic, economic and public policy changes in Malaysia have contributed to the increasing demand for a knowledgeable workforce, especially in this electronicbased society. In respect of this, many students now find that possessing higher educational qualifications is useful not only to ensure employment, but also to ensure success and marketability in an ever-evolving job market in Malaysia. Besides, we cannot deny that higher education is of obvious importance to support national economic 
objectives for every country in the world and the development of the indigenous labour forces, including the direct raising of extra-national income (Yorke, 1999).

The Malaysian government is keen on turning Malaysia into an excellent education hub, and has taken significant strides in liberalizing the educational services industry by encouraging competition amongst operators in both public and private sectors (Samsinar Md. Sidin, Siti Rahayu Hussin, \& Tan, 2003). This has resulted in an increase in the establishment of higher learning institutions, specifically private institutions such as colleges, university colleges and universities. This effort suggests that the Malaysian government is committed towards ensuring that the younger generation are well educated and belong to knowledgeable groups of people. Moreover, the Malaysian government expects that the total number of enrolment of tertiary students will increase to approximately 200,000 students by 2020 (Ministry of Higher Education Malaysia, 2011).

Many universities and colleges are offering different higher learning programs in Malaysia. As such, this has increased the competition to some extent, where students have unlimited options when selecting universities. As the options continue to increase, university selection criteria have also become more extensive and complex. Some students often ask these questions, "Which university is the best? "Am I doing the right course?", "Which university is top for programmes?", and others. In this respect, with over 200 higher educational institutions in Malaysia, choosing one to go to is never an easy task. Therefore, this study asserts to develop a valid framework of students' selection choice of higher education institution among Sarawakians.

There is also very limited literature on analysing the decision-making process of potential local students in general. As reviewed in the literature, some of the researchers have overlooked the needs of segment (Joseph \& Joseph, 2000). In fact, few studies have tried to analyse the determinants of the choice of universities among local students (Samsinar Md. Sidin, Siti Rahayu Hussin, \& Tan, 2003; Norbahiah, Misran, Sarifah Nurhanum Syed Sahuri, Norhana Arsad, Hafizah Hussain, Wan Mimmi Diyana Wan Zaki, \& Norazreen Abd Aziz, 2012; Sia, 2010). Additionally, empirical evidence on this topic in Malaysia is very limited (Abdullah Al Mamun Sarwar, Ahasanul Haque, \& Ahmad Zaki Hj Ismail, 2012). It is very complicated to understand how students select colleges of their choice to pursue their study (Samsinar Md. Sidin et al., 2003). Due to the limited literature and empirical evidence on the topic, we believe that other related studies focusing on the student's choice and criteria of selecting the institutions will be able to provide some useful insights and information on the factors influencing the students in selecting various higher learning institutions (Abdullah Al Mamun Sarwar et al., 2012). Based on the gap in the literature and empirical studies, this study is therefore to determine the factors that influence local students' choice of university as their higher learning institution. 


\section{Literature Review}

\section{High-involvement students' decision making process}

Choosing a study destination is considered a high-involvement decision as students need the right and sufficient information to guide their decisions (Binsardi \& Ekwulugo, 2003). To our knowledge, the choice of institution is difficult because the students spend time to find an institution which can match their education goals, interests, and financial constraints. Moreover, perhaps choosing the institution or programme might shape their life, future careers, and also their families (Rohaizat Baharun \& Siti Falinda Padlee, 2014). In line with this, a study of Veloutsou, Lewis, and Paton (2004) stated that decision to select a university is a difficult task for students due to the fact that such decisions often affect their future life paths (Hartono, 2012). Domino, Libraire, Lutwiller, Superczynski, and Tian (2006) described that the decision is important for students because education from universities will significantly influence students' whole life. Therefore, students and parents are very serious and careful when selecting a university to attend (Hartano, 2012).

According to Hanson and Litten's (1982) model as cited in Mubaira and Fatoki (2011), college selection is considered as a continuing process. In the higher education decision making process, typically, a student may go through four stages when choosing a study destination. Firstly, the student will recognize his/her need to further their education. This need recognition is usually triggered by an imperfect home country's education system perceived by the students. Secondly, the students will start to collect a wealth of information about potential higher education institutions via many sources to decide where to go for their tertiary education. These sources of information include university websites, word-of-mouth sources, campus visits and open days, advertisements in newspapers and magazines, as well as prospectuses, brochures and pamphlets. As noted in the literature, campus visit and open days are the most valuable sources of information for prospective students (Wiese, Heerden, Jordaan, \& North, 2009). Approximately, $84.3 \%$ of the students gather college information on their own (Samsinar Md. Sidin et al., 2003). The student usually has a set of criteria for him/herself, which is the same as the evaluation phase in consumer decision making process, as discussed earlier. Students will then compare his/her criteria to the features of the potential or targeted university to go with the other universities.

In the third stage, students collect information about potential institutions and decide whether they want to study. Again, the process through which the student goes in order to make the decision is the same as in the second stage. After that, students will experience the study period in the institution and start to generate their opinion about the institution, whether they will continue their study and recommend or advise against their institution to other prospective students. It is therefore concluded that it is important for higher education institutions to know about the students' expectations and try to live up to those expectations. 


\section{Underline Theory}

Choice Theory (also known as Perceptual Control Theory (PCT) by William Glasser (1998), it is useful therapeutic approach (Carey, 2010). Generally, Choice Theory is an internal control psychology which provides a framework to understand why and how people behave (Piltz, 2014). As cited in the study of Piltz (2014), Kemp and Piltz (1995), an individual's choice of behaviour responses could form the construct of personal responsibility and this in turn creates reflection from individual behaviour.

In relation with the concept of Choice Theory, students engage themselves in various activities to get a better life. Choice is an iterative concept which is a complex and multifactorial process involving a wide range of influences that stand upon a decision (Foskett, 1999). Every choice is a natural consequence, which produces accountability (Sequeira, 2007). According to Hemsley-Brown (1999), when the students often give practical reasons for making choices, these were usually filtered through layers of predeterminations, which were influenced by family background, culture and life history (Abdullah et al., 2012).

\section{Hypotheses developments}

\section{Job prospect}

According to Greenhaus and Callanan (1994), occupational choice is perhaps considered as one of those most influenced by family concerns (Beauregard, 2007). The research done by Smithson (1999) suggested that young people's occupational choices are influenced by the way in which they prioritize their work and family roles, and that they tend to place a high value on both work and family rather than on one or the other (Beauregard, 2007). Based on the above statements, the following hypothesis has been developed:

H1: Job perspective is positively related to students' intention to choose higher learning institution.

\section{Reputation of Institution}

Many studies indicated that the reputation of the institution highly influences an individual to choose a particular college or university as the place to pursue their study. The study of Murphy (1981) documented academic reputation and cost as the determinants of college choice (Joseph \& Joseph, 2000). This finding is in line with the study of Ancheh (2006), which notes that reputation of institution plays the most important role in attracting more students to enrol a 'dream' higher education institution. Similarly, the study conducted by Keling, Krishman, and Nurtjahja (2007) also stated that the most influential factor that students will evaluate in selecting their choice of institution was reputation of the institution (Sia, 2010). Daily, Farewell. Kumar (2010) also reported that reputation of institution was one of the most important attributes for students to pursue their study (Koe \& Siti Noraisah Saring, 2013). This finding was concurrent with the study done by Sia (2010) that institutional reputation was a powerful factor in affecting students' choice of higher education institution. Therefore, the researcher concluded that good reputation of institution positively impacts on students' choice intention, and formulated the hypothesis as follows: 
H2: Reputation of Institution is positively related to students' intention to choose higher learning institution.

\section{Location}

Strategic location is always a factor that affects students' choice of university. Sia (2010) suggested in her conceptual framework that students may choose a college which is near to their home (Koe \& Siti Noraisah Saring, 2013). Sevier (1986) discovered that college or university location can be a major factor for potential student's decision to enrol (Sia, 2010). Thus, the university that has a strategic location can be a major factor to capture student intention to pursue their study. Therefore, the following hypothesis can be suggested:

H3: Location of Institution is positively related to students' intention to choose higher learning institution.

\section{Cost}

Wagner and Fard (2009) proposed that HEI administrators, marketers and policy makers should focus on the cost of education in promoting their programs (Koe \& Siti Noraisah Saring, 2013). As stated in the literature review, students preferred to register themselves in higher education institutions which can offer them good quality courses at low costs (Ancheh, Krishnan, \& Nurtjahja, 2007; Fernandez, 2010; Sia, 2010). According to Padlee, Kamaruddin, and Baharun (2010), it was also reinforced that cost of education, such as tuition fee, accommodation fee, exchange rate, and others are the foremost factors to determining the students' choice decision. Hereby, the researcher has made the following hypothesis:

H4: Cost is positively related to students' intention to choose higher learning institution.

\section{Parental Advice}

Pimpa (2004) highlighted that family is the most influential factor for Thai students' choice of international education (Osman M. Zain, Muhammad Tahir Jan, \& Andy B. Ibrahim, 2013). Yamamoto (2006) found that Turkish students were highly influenced by their parents as well as family (Koe \& Siti Noraisah Saring, 2013). Similarly, a major study in Australia found that parental influence is particularly strong among the students when they are choosing an institution (Mazzarol \& Soutar, 2002). These findings are concurrent with the study by Mehboon, Syed Mir Muhammad Shah, and Bhutto (2012) which also pointed out that parents/friends significantly influence an individual student when selecting a higher education institution. In short, parents and peers who provide sufficient encouragement and support to students can affect their decision directly. As a result, the researcher has made the following hypothesis:

H5: Parents' Advice is positively related to students' intention to choose higher learning institution.

\section{Peer Influence}

Past studies show that peer tends to influence one for decision making on selecting higher learning institution. A study by Mohd Yusuf, Ghazali, and Abdullah (2017) found that the influence of peers significantly affected students transitioning from high school to higher education institution. Besides, peers who attended college influenced their 
friends to attend college, and the non-college bound peers also influenced their friends to attend college (Terenzini, et al., 1994). This is because peers' preferences create a social norm, called the "acceptable choice" among high school students (Fletcher 2012). Pimpa (2005) has stated that Thai students apply to Australian universities because of their peers' suggestion which is consistent with the result of Fletcher (2012). Subsequently, the following hypothesis was formulated:

H6: Reputation of Institution is positively related to students' intention to choose higher learning institution.

\section{Methodology}

The SmartPLS (version 3.2.6) was used to assess the model developed based on path modelling followed by bootstrapping. A total of 500 resamples were used to generate standard errors of the estimation and t-values by running the bootstrapping process. The quantitative method was employed to collect the data. A self-administrated survey was used to obtain the primary data. The respondents of this study were derived from local secondary schools who were willing to provide the first hand information. The sample size for this study was 324, based on Sekaran and Bougie (2013) who concurs with Roscoe (1975) on the sufficient sample size number for most studies being between 30 to 500. Purposive sampling method was used to select accurate respondents. The questionnaire was written in English because these representative respondents were expected to be proficient in English. The questionnaire was divided into two sections. Section A consists of multiple items to measure the measurement of the studied research model. However, Section B covered the relevant demographic information of the respondents. A total of 42 items were modified from several previous studies. All chosen variables used the multiple items and 5 point Likert scale was used for measurement.

\section{Findings}

Assessment of Measurement Model

To measure the construct validity, Confirmatory factor analysis (CFA) was conducted, covering composite reliability, convergent validity, and discriminant validity. Loading and cross loading results are revealed in Table 1, which illustrates that the loadings for all items were greater than the required minimum value of 0.70 , suggested by (Hair, Gabriel, \& Patel, 2014). This validated that all the items measuring a specific construct loaded extremely on their construct and loaded lower on other construct. Theoretically, in the loading and cross-loading matrices, all measurement items should load above the respective construct than other constructs. Interestingly, as presented in Table 2, all AVE values exceeded 0.5 (Henseler, Ringle, \& Sinkovics, 2009). The composite reliability (CR) values were above 0.8 (Gefen, Straub, \& Boudreau, 2000). This is therefore to summarize that convergent validity was established. Furthermore, the Cronbach Alpha values for all chosen variables were also above the minimum cut off value of 0.7 (refer to Table 3).

To assess discriminant validity, following Fornell and Larcker's (1981) criterion, the value of AVE was square roots and testified against the inter-correlation of the construct with other constructs in the research model and all values indicated that as greater than 
each constructs' correlation (Chin, 2010) (refer to Table 4). In summary, the measurement model was completely satisfactory with the evident results of reliability, convergent validity, and discriminant validity. Additionally, the coefficient of determination (R2) was 0.281 for secondary school students' intention to choose higher learning institution, which explained more than $28.1 \%$ of the construct.

Table 1 Loading and Cross Loading

\begin{tabular}{|c|c|c|c|c|c|c|c|}
\hline & Location & $\begin{array}{l}\text { University } \\
\text { Reputation }\end{array}$ & $\begin{array}{l}\text { Job } \\
\text { Prospective }\end{array}$ & Peer & $\begin{array}{l}\text { Parent } \\
\text { Advice }\end{array}$ & Cost & $\begin{array}{l}\text { Student } \\
\text { Intention }\end{array}$ \\
\hline location_1 & 0.897 & 0.517 & 0.486 & 0.122 & 0.261 & 0.427 & 0.290 \\
\hline location_2 & 0.851 & 0.526 & 0.457 & 0.113 & 0.266 & 0.467 & 0.236 \\
\hline location_4 & 0.837 & 0.501 & 0.479 & 0.154 & 0.322 & 0.475 & 0.284 \\
\hline location_5 & 0.858 & 0.536 & 0.533 & 0.148 & 0.275 & 0.524 & 0.232 \\
\hline uni_reputation_6 & 0.544 & 0.887 & 0.703 & 0.040 & 0.301 & 0.586 & 0.367 \\
\hline uni_reputation_7 & 0.563 & 0.872 & 0.702 & 0.029 & 0.297 & 0.605 & 0.389 \\
\hline uni_reputation_8 & 0.537 & 0.893 & 0.709 & -0.008 & 0.345 & 0.641 & 0.387 \\
\hline uni_reputation_9 & 0.505 & 0.851 & 0.727 & -0.014 & 0.304 & 0.603 & 0.355 \\
\hline uni_reputation_10 & 0.500 & 0.895 & 0.723 & -0.002 & 0.303 & 0.618 & 0.404 \\
\hline job_prospects_12 & 0.448 & 0.659 & 0.841 & 0.132 & 0.317 & 0.574 & 0.349 \\
\hline job_prospects_13 & 0.532 & 0.733 & 0.887 & 0.096 & 0.367 & 0.627 & 0.372 \\
\hline Job_prospects_14 & 0.504 & 0.701 & 0.900 & 0.124 & 0.383 & 0.610 & 0.374 \\
\hline job_prospects_15 & 0.488 & 0.728 & 0.858 & 0.082 & 0.353 & 0.589 & 0.376 \\
\hline peer_16 & 0.164 & 0.057 & 0.125 & 0.768 & 0.276 & 0.119 & 0.126 \\
\hline peer_17 & 0.166 & 0.099 & 0.172 & 0.845 & 0.348 & 0.114 & 0.153 \\
\hline peer_18 & 0.164 & -0.017 & 0.084 & 0.876 & 0.366 & 0.103 & 0.115 \\
\hline peer_19 & 0.105 & -0.024 & 0.091 & 0.847 & 0.310 & 0.131 & 0.161 \\
\hline peer_20 & 0.017 & -0.123 & -0.002 & 0.784 & 0.247 & -0.014 & 0.091 \\
\hline parent_advice_22 & 0.233 & 0.318 & 0.358 & 0.342 & 0.803 & 0.330 & 0.324 \\
\hline parent_advice_23 & 0.331 & 0.410 & 0.380 & 0.196 & 0.840 & 0.387 & 0.420 \\
\hline parent_advice_24 & 0.290 & 0.266 & 0.335 & 0.307 & 0.848 & 0.268 & 0.344 \\
\hline parent_advice_25 & 0.159 & 0.062 & 0.201 & 0.439 & 0.705 & 0.153 & 0.257 \\
\hline cost_26 & 0.479 & 0.565 & 0.601 & 0.130 & 0.328 & 0.810 & 0.276 \\
\hline cost_27 & 0.474 & 0.647 & 0.625 & 0.057 & 0.295 & 0.888 & 0.369 \\
\hline cost_28 & 0.461 & 0.563 & 0.538 & 0.115 & 0.284 & 0.866 & 0.303 \\
\hline cost_29 & 0.378 & 0.536 & 0.507 & 0.110 & 0.367 & 0.779 & 0.265 \\
\hline cost_30 & 0.495 & 0.595 & 0.611 & 0.106 & 0.297 & 0.853 & 0.346 \\
\hline intention_39 & 0.254 & 0.355 & 0.294 & 0.093 & 0.346 & 0.295 & 0.820 \\
\hline intention_40 & 0.236 & 0.346 & 0.300 & 0.092 & 0.360 & 0.308 & 0.849 \\
\hline intention_41 & 0.250 & 0.398 & 0.416 & 0.129 & 0.332 & 0.336 & 0.830 \\
\hline intention_42 & 0.262 & 0.319 & 0.368 & 0.216 & 0.369 & 0.291 & 0.781 \\
\hline
\end{tabular}

Note: Bold values are loadings for items that are above the recommended value 0.5 
Table 2 The Results of Measurement Model

\begin{tabular}{|c|c|c|c|c|}
\hline Construct & Items & Loading & $\begin{array}{c}\text { Average } \\
\text { Variance } \\
\text { Extracted } \\
(\text { AVE) }\end{array}$ & $\begin{array}{l}\text { Composite } \\
\text { Reliability } \\
\text { (CR) }\end{array}$ \\
\hline \multirow{4}{*}{ Location } & location_1 & 0.897 & 0.742 & 0.920 \\
\hline & location_2 & 0.851 & & \\
\hline & location_4 & 0.837 & & \\
\hline & location_5 & 0.858 & & \\
\hline \multirow{5}{*}{$\begin{array}{l}\text { University } \\
\text { reputation }\end{array}$} & uni_reputation_6 & 0.887 & 0.774 & 0.945 \\
\hline & uni_reputation_7 & 0.872 & & \\
\hline & uni_reputation_8 & 0.893 & & \\
\hline & uni_reputation_9 & 0.851 & & \\
\hline & uni_reputation_10 & 0.895 & & \\
\hline \multirow{4}{*}{$\begin{array}{l}\text { Job } \\
\text { Perspective }\end{array}$} & job_prospects_12 & 0.841 & 0.760 & 0.927 \\
\hline & job_prospects_13 & 0.887 & & \\
\hline & Job_prospects_14 & 0.900 & & \\
\hline & job_prospects_15 & 0.858 & & \\
\hline \multirow{5}{*}{$\begin{array}{l}\text { Peer's } \\
\text { Influence }\end{array}$} & peer_16 & 0.768 & 0.681 & 0.914 \\
\hline & peer_17 & 0.845 & & \\
\hline & peer_18 & 0.876 & & \\
\hline & peer_19 & 0.847 & & \\
\hline & peer_20 & 0.784 & & \\
\hline \multirow{4}{*}{$\begin{array}{l}\text { Parental' } \\
\text { Advice }\end{array}$} & parent_advice_22 & 0.803 & 0.642 & 0.877 \\
\hline & parent_advice_23 & 0.840 & & \\
\hline & parent_advice_24 & 0.848 & & \\
\hline & parent_advice_25 & 0.705 & & \\
\hline \multirow{5}{*}{ Cost } & cost_26 & 0.810 & 0.706 & 0.923 \\
\hline & cost_27 & 0.888 & & \\
\hline & cost_28 & 0.866 & & \\
\hline & cost_29 & 0.779 & & \\
\hline & cost_30 & 0.853 & & \\
\hline \multirow{4}{*}{$\begin{array}{l}\text { Student } \\
\text { Intention }\end{array}$} & intention_39 & 0.820 & 0.673 & 0.892 \\
\hline & intention_40 & 0.849 & & \\
\hline & intention_41 & 0.830 & & \\
\hline & intention_42 & 0.781 & & \\
\hline
\end{tabular}

Note: a Composite Reliability $(\mathbf{C R})=$ (square of the summation of the factor loadings) / \{ (square of the summation of the factor loadings) + (square of the summation of the error variances) $\}$

b Average Variance Extracted (AVE) = (summation of the square of the factor loadings) / \{ (summation of the square of the factor loadings) + (summation of the error variances) $\}$

Table 3: Results of Reliability Testing

\begin{tabular}{llccc}
\hline \multicolumn{1}{c}{ Construct } & \multicolumn{1}{c}{ Items } & $\begin{array}{c}\text { Cronbach's } \\
\text { Alpha }\end{array}$ & Loading Range & $\begin{array}{c}\text { Number of } \\
\text { Items }\end{array}$ \\
\hline Location & $\begin{array}{l}\text { location_1 } \\
\text { location_2 }\end{array}$ & 0.884 & $0.837-0.897$ & $4(5)$ \\
& lon & & & \\
\hline
\end{tabular}




\begin{tabular}{|c|c|c|c|c|}
\hline & $\begin{array}{l}\text { location_4 } \\
\text { location_5 }\end{array}$ & & & \\
\hline \multirow{5}{*}{$\begin{array}{l}\text { University } \\
\text { reputation }\end{array}$} & uni_reputation_6 & 0.927 & $0.851-0.895$ & $5(5)$ \\
\hline & uni_reputation_7 & & & \\
\hline & uni_reputation_8 & & & \\
\hline & uni_reputation_9 & & & \\
\hline & uni_reputation_10 & & & \\
\hline \multirow{4}{*}{ Job Perspective } & job_prospects_12 & 0.895 & $0.841-0.900$ & $4(5)$ \\
\hline & job_prospects_13 & & & \\
\hline & Job_prospects_14 & & & \\
\hline & job_prospects_15 & & & \\
\hline \multirow{5}{*}{ Peer's Influence } & peer_16 & 0.883 & $0.768-0.876$ & $5(5)$ \\
\hline & peer_17 & & & \\
\hline & peer_18 & & & \\
\hline & peer_19 & & & \\
\hline & peer_20 & & & \\
\hline \multirow{4}{*}{ Parental's Advice } & parent_advice_22 & 0.815 & $0.705-0.848$ & $4(5)$ \\
\hline & parent_advice_23 & & & \\
\hline & parent_advice_24 & & & \\
\hline & parent_advice_25 & & & \\
\hline \multirow{5}{*}{ Cost } & cost_26 & 0.895 & $0.779-0.888$ & $5(5)$ \\
\hline & cost_27 & & & \\
\hline & cost_28 & & & \\
\hline & cost_29 & & & \\
\hline & cost_30 & & & \\
\hline \multirow{4}{*}{ Student Intention } & intention_39 & 0.838 & $0.781-0.849$ & $4(5)$ \\
\hline & intention_40 & & & \\
\hline & intention_41 & & & \\
\hline & intention_42 & & & \\
\hline
\end{tabular}

Note: Final items number (initial numbers)

Table 4 Discriminant validity of constructs

\begin{tabular}{lccccccc}
\hline & Cost & $\begin{array}{c}\text { Job } \\
\text { Prospective }\end{array}$ & Location & $\begin{array}{c}\text { Parent } \\
\text { Advice }\end{array}$ & Peer & $\begin{array}{c}\text { Student } \\
\text { Intention }\end{array}$ & $\begin{array}{c}\text { University } \\
\text { Reputation }\end{array}$ \\
\hline Cost & $\mathbf{0 . 8 4 0}$ & & & & & & \\
\hline $\begin{array}{l}\text { Job } \\
\text { Prospective }\end{array}$ & 0.688 & $\mathbf{0 . 8 7 2}$ & & & & & \\
\hline Location & 0.546 & 0.566 & $\mathbf{0 . 8 6 1}$ & & & & \\
\hline $\begin{array}{l}\text { Parental's } \\
\text { Advice }\end{array}$ & 0.369 & 0.408 & 0.327 & $\mathbf{0 . 8 0 1}$ & & & \\
\hline $\begin{array}{l}\text { Peer's } \\
\text { influence }\end{array}$ & 0.120 & 0.124 & 0.156 & 0.379 & $\mathbf{0 . 8 2 5}$ & & \\
\hline $\begin{array}{l}\text { Student } \\
\text { Intention }\end{array}$ & 0.375 & 0.422 & 0.305 & 0.429 & 0.162 & $\mathbf{0 . 8 2 0}$ & \\
\hline $\begin{array}{l}\text { University } \\
\text { Reputation }\end{array}$ & 0.694 & 0.810 & 0.602 & 0.352 & 0.010 & 0.433 & $\mathbf{0 . 8 8 0}$ \\
\hline
\end{tabular}


Note: Diagonals represent the square root of the average variance extracted while the other entries represent the correlations

\section{Assessment of Structural Model}

The structural model was then tested by analyzing the inner model. Figure 1 and Table 4 shows the findings of hypotheses testing. Bootstrapping was utilized to generate tvalue for each of the hypothesized relationship and the potential impact of covariates. A 500 bootstrap re-sampling of data was conducted to assess the developed hypotheses (Hair, Hult, Ringle, \& Sarstedt, 2014). A global fit measure (GOF) was performed to determine the overall prediction power of a complex model (Akter, D'Ambra, \& Ray, 2011). As displayed in Table 4, the valuation pf path co-efficient which was represented by Beta values for each path relationship. To summarize, only two hypotheses were supported. The findings indicated that university's reputation $(\beta=0.241, \mathrm{P}<0.01)$ and parents' advice $(\beta=0.282, \mathrm{P}<0.01)$ were positively significant in relation to student intention to choose higher institutions. As for location $(\beta=0.010, \mathrm{P}<0.05)$, job perspective $(\beta=0.076, P<0.05)$, peer influence $(\beta=0.039, \mathrm{P}<0.05)$, and costs of program $(\beta=0.052, P<0.05)$, these were not found to have positive effects on student intention to choose higher learning institution. Thus, it is therefore relevant to conclude that $\mathrm{H} 2$ and $\mathrm{H} 5$ were supported and $\mathrm{H} 1, \mathrm{H} 3, \mathrm{H} 4$, and $\mathrm{H} 6$ were rejected. Moreover, the variation inflation factor (VIF) values displayed in Table 4, shows a range between 1.230 to 3.589 (less than 10). It showed that no multicollinearity exists among the studies constructs (Bock, Zmud, \& Lee, 2005). In addition, Blindfolding procedures were also performed for Q2 value, which was 0.436 , which is bigger than zero value.

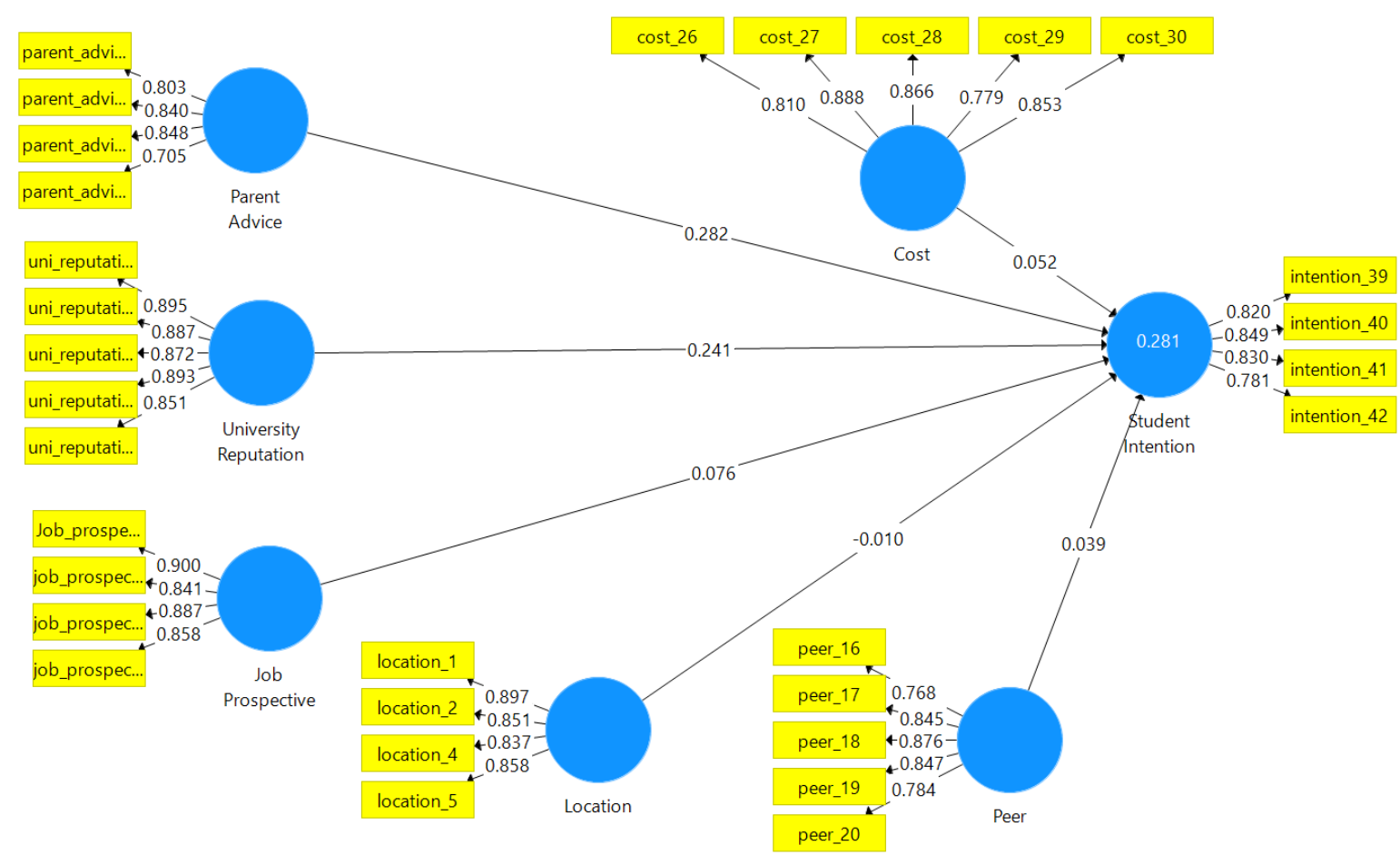

Figure 1 Research Framework with t-value 
Table 4 Path Coefficients and Hypothesis Testing

\begin{tabular}{|c|c|c|c|c|c|}
\hline $\begin{array}{l}\text { Hypo } \\
\text { thesis }\end{array}$ & Relationship & $\begin{array}{l}\text { Coeff } \\
\text { icient }\end{array}$ & $\begin{array}{l}\text { t- } \\
\text { val } \\
\text { ue }\end{array}$ & $\begin{array}{l}\text { Deci } \\
\text { sion }\end{array}$ & $\begin{array}{l}\text { VI } \\
\text { F }\end{array}$ \\
\hline H1 & $\begin{array}{l}\text { Location students' intention towards higher education } \\
\text { institution. }\end{array}$ & $-\overline{-}$ & $\begin{array}{l}0.1 \\
64\end{array}$ & No & $\begin{array}{l}1 . \\
71 \\
0\end{array}$ \\
\hline $\mathrm{H} 2$ & $\begin{array}{l}\text { University reputation has a positive impact on } \\
\text { students' intention towards higher education } \\
\text { institution. }\end{array}$ & 0.241 & $\begin{array}{l}3.0 \\
32\end{array}$ & Yes & $\begin{array}{c}3 . \\
58 \\
9\end{array}$ \\
\hline H3 & $\begin{array}{l}\text { Job perspective has a positive impact on students' } \\
\text { intention towards higher education institution. }\end{array}$ & 0.076 & $\begin{array}{l}0.8 \\
67\end{array}$ & No & $\begin{array}{c}3 . \\
34 \\
7\end{array}$ \\
\hline H4 & $\begin{array}{l}\text { Peer influence has a positive impact on students' } \\
\text { intention towards higher education institution. }\end{array}$ & 0.039 & $\begin{array}{l}0.6 \\
95\end{array}$ & No & $\begin{array}{c}1 . \\
23 \\
0\end{array}$ \\
\hline H5 & $\begin{array}{l}\text { Parent advice has a positive impact on students' } \\
\text { intention towards higher education institution. }\end{array}$ & 0.282 & $\begin{array}{l}3.9 \\
74\end{array}$ & Yes & $\begin{array}{c}1 . \\
41 \\
3\end{array}$ \\
\hline H6 & $\begin{array}{l}\text { Cost has a positive impact on students' intention } \\
\text { towards higher education institution }\end{array}$ & 0.052 & $\begin{array}{l}0.7 \\
30\end{array}$ & No & $\begin{array}{c}2 . \\
22 \\
4\end{array}$ \\
\hline
\end{tabular}

Note: $t$-value $>1.96(p<0.05 *) ; t$-value $>2.58(p<0.01 * *)$

\section{Discussion}

The present study was carried out to investigate the positive impact of strategic location, university's reputation, job perspective, peer's influence, parental advice, and cost of program factors in students' choosing intention of higher learning institution in the context of Sibu, Sarawak. As projected, the results of the statistical analysis indicated that parental advice and reputation of an institution may influence an individual secondary school student to choose their dream university. According to Powers (1988), academic quality, quality and reputation of the institution were leading factors when choosing a program in a higher learning institution (Chiu, 1999). Similarly, Donaldson and McNicholas (2004) revealed that reputation of institution significantly led to student's choice intention (Yamamoto, 2006). A possible reason could be that Malaysian parents or Sarawakian parents are likely to impose their goals on their child. To them, having a good education for their children is the best investment. Another reason could be due to the possibility that some children do not want their parents to be disappointed, and are engaged in the choices of their parents, rather than their own choice. Apart from parental advice, reputation of an institution might influence secondary school students to choose their university. This is because a strong university image may support 
research, business engagement, and recruitment that could help students to find a good career in the future. Universities that do not have good reputations tends to have less competitive advantage within the industry.

On the other hand, the study reported that location of institution, job perspective, peer influence, and cost of program were negatively related to students' intention to choose higher learning institution. This is in line with the findings of Oosterbeck, Groot, and Hartog (1992), whereby career prospects and higher status were insignificant to the choice of university and program selection. The findings of this study were contrary to the expectations of previous research (Chen \& Zimitat, 2006; Choy, 2001; Gibbons \& Vignoles, 2012; Millar \& Liciardi, 2003; Moogan \& Baron, 2001; Saenz, Marcoulides, Junn, \& Young, 1999; Veloutsou, Lewis, \& Patron, 2004). A possible reason could be that the majority of children (secondary school students) are too dependent on their parents or perhaps, they do not know what they want and where they should pursue their tertiary education. Another reasonable reason is perhaps due to insecure processes of higher learning institution selection and fear of unemployment upon graduating from a course, resulting in a majority of the students not being able to make the right choice. This insignificant finding may also be related to culture or subcultural reasons at home, whereby the children are too pampered and are too dependent on their families.

\section{Limitation}

Similar to other studies, research limitations of the study need to be considered and presented. Firstly, the study sample lacked diversity. Methodologically, this survey concentrated on secondary school students who are studying in secondary schools from urban areas only, and did not cover students from rural areas. Thus, this study is not representative of the whole population of Sarawak. Another related problem with the sample is the sample size. Although the sample size of this study, 324 respondents, is acceptable, a maximized sample study is required to generate stronger generalizations that can represent the whole population. The third constraint concerns the nature of the study. The current research model explained $26.1 \%$ of the variance in student intention to choose higher learning institution. The remaining $73.9 \%$ for student intention to choose higher learning institution remains unexplained.

\section{Conclusion}

In summary, the findings have provided empirical findings that both university reputation and parental advice play principle factors in student's choice of higher education. Therefore, higher administrators (e.g., stakeholders), head of the marketing department, and top management (decision makers) should focus on the proposed two main determinants which are reputation of university and parental advice. Based on the results, top management should do something in order to build and strengthen brand equity for their institution. The marketers ought to develop a specific marketing plan during student recruitment. From the theoretical perspective, this study proposed and validated a new model for destination choice of higher learning education among the local students, and the findings provide a basis for the further study of this topic. This new proposed model contributes to the body of knowledge on students' choice of higher learning institution in the context of Sarawak. 


\section{Acknowledgement}

This research is ostensibly supported by UCTS research grant (UCTS/Research/<1/2014/04>(01) for its financial support.

\section{References}

Abdullah Al Mamun Sarwar., Ahasanul Haque., \& Ahmad Zaki Hj Ismail. (2012). Measuring Students' Perception towards University Selection: An Empirical Investigation on Malaysian Postgraduate Students. International Journal of Research in Commerce, Economics \& Management, 2(9): 13-20.

Ahmad Kainuwa \& Najeemah Binti Mohammad Yusuf. (2013). Infleunce of socioeconomic and educational background of parents on their children's education in Nigeria. International Journal of Scientific and Research publications, 3(10), 1-8.

Akter, S., D’Ambra, J., \& Ray, P. (2011). Trustworthiness in mHealth Information Services: an assessment of hierarchical model with mediating and moderating effects using partial least square (PLS). Journal of the American Society for Information Science and Technology, 62(1), 100-116.

Ancheh, K.S.B. (2006). Institutional Factors Attracting Students to Malaysian Institutions of Higher Education. International Review of Business Research Papers, 2(1): 46-64.

Ancheh, K.S.B., Krishnan, A., \& Nurtjahja, O. (2007). Evaluative Criteria for Selection of Private Universities and Colleges in Malaysia. Journal of International Management Studies. 2(1): 1-11.

Barden, L. et al. (1991) An Analysis of Student Loan option. London: The Committee of Vice-Chancellors and Principals of the Universities of the United Kingdom (CVCP).

Beauregard, T.A. (2007). Family Influence on the Career Life Cycle.

Binsardi, A. \& Ekwulugo, F. (2003). International Marketing of British Education: Research on Students' perception and the UK market penetration. Marketing Intelligence \& Planning, 21/5: 318-327.

Bock, G.W., Zmud, R.W., Kim, Y.G., \& Lee, J.N. (2005). Behavioural intention formation in knowledge sharing: examining the roles of extrinsic motivators, socialpsychological forces, and organizational climate. MIS Quarterly, 29(1), 87-111.

Carey, T.A. (2010). Choice Theory and PCT: What are the differences and do they matter anyway? International Journal of Reality Therapy, 21(2): 23-32. 
Chen, C.H. \& Zimatat, C. (2006). Understanding Taiwanese students' decision-making factors regarding Australian international higher education. International Journal of Educational Management, 20(2), 91-100.

Chin, W.W. (2010). How to Write Up and Report PLS Analyses. In Handbook of Partial Least Squares: Concept, Methods and Applications by Esposito, V., et al., (Eds). P. 655-690.

Chiu, R. (1999). Relationships between motivators and criteria in the selection of a distance learning MBA programs in Hong Kong. Career Development International, 4(1), 26-33.

Choy, S.P. (2001). Students whose parents did not go to college: postsecondary access, persistence, and attainment. The condition of Education, 18-44.

Daily, C.M., Farewell, S., \& Kumar, G. (2010). Factors Influencing the University Selection of International Studies. Academy of Educational Leadership Journal, 14(3), 59-75.

Domino, S., Libraire, T., Lutwiller, D., Superczynski, S. \& Tian, R. (2006). Higher Education Marketing Concerns: Factors Influence Students' Choice of College. The Business Review, 6(2), 101-111

Donalson, W.G. \& Mcnicholas, C. (2004). Understanding the postgraduate education market for UK based students. Journal of Nonprofit \& Voluntary Sector Marketing, 9(4), 346-60.

Fernandez, J.L. (2010). An Exploratory Study of Factors Influencing the Decision of Students to Study at Universiti Sains Malaysia. Kajian Malaysia, 28(2), 107-136.

Fletcher, J.M. (2012). Similarity in peer college preferences: New evidence from Texas. Social Science Research, 41(2), 321-330.

Gibbons, S. \& Vignoles, A. (2012). Geography, choice and participation in higher education in England. Regional Science and Urban Economics, 42, 98-113.

Greenhaus, J. H. \& Callanan, G. A. (1994). Career management. London: Dryden Press.

Smithson, J. (1999). Equal choices, different futures: Young adults talk about work and family expectations. Psychology of Women Section Review, 1, 43-57.

Hair, J.F., Hult, G.T.M., Ringle, C.M., \& Sarstedt, M. (2014). A primer on partial least squares structural equation modelling (PLS-SEM), Los Angeles: Sage Publication.

Hartono, A. (2012). Information Requirement in the Selection on Indonesian Higher Education Institution: Evidence from Education Expo Visitors. Australian Journal of Business and Management Research, 2(9): 26-30. 
Joseph, M. \& Joseph. B. (2000). Indonesian Students' Perceptions of Choice Criteria in the selection of a Tertiary Institution: Strategic Implications. International Journal of Educational Management, 14/1: 40-44.

Keling, S.B.A., Krishnan, A., \& Nurtjahja, O. (2007). Evaluative criteria for selection of private universities and colleges in Malaysia. Journal of International Management Studies, 2(1), 1-11.

Koe, W.L. \& Siti Noraisah Saring. (2013). Factors Influencing the Foreign Undergraduates' Intention to Study at Graduate School of a Public University. Jurnal Kemanusiaan, 19: 57-68.

Mazzarol, T. \& Soutar, G,N. (2002). Push-pull factors influencing international student destination choice. The International Journal of Educational Management, 16(2), 82-90.

Mehboob, F., Syed Mir Muhammad Shah., \& Bhutto, N.A. (2012). Factors Influencing Student's Enrolment Decisions in Selection of Higher Education Institutions. Interdisciplinary Journal of Contemporary Research in Business, 4(5): 558-568.

Ministry of Higher Education. (2011). Internationalization Policy for Higher Education Malaysia.

Mohd Yusuf, B., M. Ghazali, M., \& Abdullah, M. (2017). Factors influencing local and international students' decision in choosing public higher learning institutions in Northern Region of Malaysia. International Journal of Social Sciences, 48(1) 2941.

Moogan, Y.V. \& Baron, S. (2001). Timing and trade-offs in the marketing of higher education courses: a conjoint approach. Marketing Intelligence \& Planning. 19(3), 179-187.

Mubaira, T.C. \& Fatoki, O. (2011). The Determinants of the choice of universities by foreign business students in South Africa. Asian Journal of Business and Management Sciences, 1(8): 09-21.

Murphy, P. (1981). Consumer buying roles in college choice'. College and University. $56,140-150$.

Oosterbeck, H., Groot, W., \& Hartog, J. (1992). An empirical analysis of university choice and earnings. De Economist, 140(3), 293-309.

Norbahiah, Misran., Sarifah Nurhanum Syed Sahuri., Norhana Arsad., Hafizah Hussain., Wan Mimmi Diyana Wan Zaki., \& Norazreen Abd Aziz. (2012). Malaysian Matriculation Student's Factors in Choosing University and Undergraduate Program. Asian Social Science, 8(16), 222-231.

Osman, S., Chan, Y.F.B., \& Choo, B.H. (2010). Undergraduate and online purchasing Behavior. Canadian Center of Science and Education, 6(10), 133-146. 
Padlee, S.F., Kamaruddin, A.R., \& Baharun, R. (2010). International Students' Choice Behavior for Higher Education at Malaysian Private Universities. International Journal of Marketing Studies. 2(2): 202-211.

Piltz, W. (2014). Applying Choice Theory and Reflection to Enhance Student Outcomes in Group Dynamics. Retrieved on 23 September 2014. Retrieved from http://fulltext.ausport.gov.au/fulltext/2002/achper/Piltz2.pdf

Pimpa, N. (2003). The influence of family on Thai students' choices of international education. International Journal of Educational Management, 17(5), 211-219.

Powers, T.L. (1988). The consumer perspective on business school evaluation. Journal of Marketing for Higher Education, 1(1), 109-31.

Rohaizat Baharun. \& Siti Falinda Padlee. (2014). Why Malaysia? International Students Choice Criteria for Higher Learning's Selection. Retrieved on 23 July 2014. Retrieved from http://www.amaquen.com/files/CIMQUSEF2008_Rohaizat.pdf

Saenz, T., Marcoulides, G.A., Junn, E., \& Young, R. (1999). The relationship between college experience and academic performance among minority students. The International Journal of Educational Management, 13(4), 199-207.

Samsinar Md. Sidin, Siti Rahayu Hussin., \& Tan, H.S. (2003). An Exploratory Study of Factors Influencing the College Choice Decision of Undergraduate Students in Malaysia. Asia Pacific Management Review, 8(3): 259-280.

Sekaran, U. \& Bougie, R. (2013). Research methods for business: a skill-building approach (sixth ediction). New York; John Wiley and Sons Ltd.

Sia, K.M.J. (2010). Institutional Factors Influencing Students' College Choice Decision in Malaysia: A Conceptual Framework. International Journal of Business and Social Science, 1(3): 53-58.

Terenzini, P., Rendon, L., Upcraft, M., Millar, S., Allison, K., Gregg, P., \& Jalomo, R. (1994). The transition to college: Diverse students, diverse stories. Research in Higher Education, 35(1), 57-73.

Veloutsou, C., Lewis, J., \& Patron, R.A. (2004). University Selection: Information Requirement and Importance. The International Journal of Educational Management, 18(3), 160-171.

Wagner, K. \& Fard, P.Y. (2009). Factors Influencing Malaysian Students' Intention to Study at a Higher Educational Institution. E-Leader Kuala Lumpur.

Wiese, M., Heerden, N. Van., Jordaan, Y., \& North, E. (2009). A Marketing Perspective on Choice Factors Considered by South African First-Year Students in Selecting a Higher Education Institution. Southern African Business Review, 13(1), 39-60. 
Yamamoto, G.T. (2006). University Evaluation-selection: a Turkish Case. International Journal of Educational Management, 20(7), 559-569.

Yorke, M. (1999). Assuring quality and standards in globalised higher education. Quality Assurance in Education, 7(1), 14-24. 